\title{
Kebijakan Pengelolaan Air Limbah Dalam Penanganan Limbah Batik Di Kota Pekalongan Yuki Aliffenur Romadhon ${ }^{1}$
}

\begin{abstract}
Since batik is recognized by UNESCO as a nation heritage, batik industry in Pekalongan is increasing, but it caused environmental issues. Then, the government of Pekalongan issued local regulation No. 9 of 2015 about waste water management to minimalized the waste impact in Pekalongan. The sustainable development can be meant as a development concept which fulfills needs of the present without forfeiting the fulfillment rights of needs for future generation. There are three understanding apects in the sustainable development, such as social aspect, economy and environment. Generally, the implementation of local regulation No. 9 of 2015 about waste water management in Pekalongan is a balancer of the sustainable development from batik industry which has been done. There are three sustainable development principles which are suitable with local regualation No. 9 of 2015, such as principle of intergenerational equity, principle of integration between environmental protection and development, and principle of preventive measure. In its implementation, these principles have been already done, but the use of IPAL which has not been maximized caused less water quality standard and become an indication of river pollution.
\end{abstract}

Keywords: batik, waste water, local regulation, sustainable development

\begin{abstract}
Abstrak
Semenjak diakuinya batik oleh UNESCO sebagai warisan bangsa, industri batik di Kota Pekalongan semakin meningkat, namun hal tersebut menimbulkan peramasalahan lingkungan. Pemerintah Kota Pekalongan kemudian mengeluarkan Perda No 9 tahun 2015 tentang pengelolaan Air Limbah guna meminimalisisr dampak limbah di Kota Pekalongan. Pembangunan berkelanjutan dapat diartikan sebagai konsep pembangunan yang memenuhi kebutuhan masa kini tanpa mengorbankan hak pemenuhan kebutuhan-kebutuhan pada generasi yang akan datang. Terdapat tiga aspek pemahaman dalam pembangunan berkelanjutan, yaitu aspek sosial, ekonomi dan lingkungan. Secara umum implementasi Perda Kota Pekalongan No 9 Tahun 2015 Tentang Pengelolaan Air Limbah merupakan suatu penyeimbang dari pembangunan berkelanjutan dari industri batik yang telah terlaksana. Terdapat tiga prinsip pembangunan berkelanjutan yang sesuai dengan Perda No 9 Tahun 2015, yaitu prinsip keadilan antar generasi (Intergenerational equity), Prinsip Keterpaduan antara Perlindungan Lingkungan Hidup dan Pembangunan, dan prinsip tindakan pencegahan. Pada implementasinya, semua sudah terlaksana, namun penggunaan IPAL yang belum maksimal sehingga menimbulkan kadar baku mutu air diatas yang seharusnya dan menjadi indikasi pencemaran sungai.
\end{abstract}

Kata-kata kunci: batik, air limbah, peraturan daerah, pembangunan berkelanjutan

\section{Pendahuluan}

Indonesia merupakan negara yang masih menitikberatkan kepada pembangunan infrastruktur dan pertumbuhan ekonomi untuk kesejahteraan masyarakat. Sektor industri merupakan sektor percepatan laju ekonomi. Industri batik adalah salah satu industri penggerak ekonomi. Batik Indonesia semakin berkembang tidak hanya sebagai budaya tetapi juga sebagai identitas dan jati diri bangsa setelah memperoleh pengakuan dari United Nation Educational, Scientific and Cultural Organization (UNESCO) pada tanggal 2 oktober 2009. Banyak masyarakat yang Mahasiswa Pasca Sarjana Ilmu Lingkungan, Universitas
yukialiffenurromadhon@gmail.com 
mengembangkan batik di beberapa kota di Indonesia. Kota Pekalongan merupakan kota yang terkenal dengan produksi batiknya. Banyak masyarakat Kota Pekalongan menjadi pengusaha batik. Pada umumnya, industri batik di Kota Pekalongan merupakan industri rumahan atau Usaha Kecil Menengah (UKM) (Isnawati, 2014).

Setiap tahunnya, perputaran uang di Kota Pekalongan hampir seluruhnya dihasilkan dari bisnis batik. Baik di pelosok, sepanjang jalan raya, maupun di sudut Kota Pekalongan, nuansa batik sangat terasa. Aktivitas bisnis kebanyakan digerakkan oleh bisnis batik mulai dari penyedia bahan baku batik seperti canting, malam, kompor, sampai beberapa butik yang secara khusus memajang hasil produksi batik. Secara adminitratif, Kota Pekalongan terdiri dari empat kecamatan, yaitu Kecamatan Pekalongan Barat, Kecamatan Pekalongan Timur, Kecamatan Pekalongan Utara, serta Kecamtan Pekalongan Selatan. Sistem pengembangan wilayah Provinsi Jawa Tengah menetapkan Kota Pekalongan sebagai bagian dari simpul utama dari kawasan Petanglong (Kota Pekalongan, Kabupaten Batang, Kabupaten Pekalongan). Kawasan ini merupakan kawasan strategis dari sudut kepentingan pertumbuhan ekonomi. Posisi strategis Kota Pekalongan di jalur Pantura Jawa membuat Kota Pekalongan memiliki keunggulan komparatif dibandingkan daerah lain yang diharapkan menjadi penggerak bagi kemajuan dan peningkatan kesejahteraan masyarakat secara berkelanjutan (Pemerintah Kota Pekalongan, 2016).

Namun, semakin meningkatnya industri batik di Kota Pekalongan menimbulkan peramasalahan lingkungan. Tercatat ada 714 industri batik di Kota Pekalongan yang menyumbang kurang lebih 26,29\% terhadap Pendapatan Asli Daerah (PAD) Kota Pekalongan (Rusda, 2015). Di sisi lain, industri batik merupakan industri yang sangat potensial menghasilkan limbah yang berupa logam berat. Secara umum, sumber air limbah batik berasal dari proses pewarnaan dan bahanbahan sintetik yang sukar larut atau diuraikan. Limbah zat warna yang dihasilkan dari industri batik merupakan senyawa organik nonbiodegradable yang dapat menyebabkan pencemaran pada perairan sungai (Heryando, 2004).

Sumber daya air merupakan komponen ekosistem yang sangat penting bagi kehidupan manusia. Kebutuhan terhadap air semakin meningkat, baik untuk kebutuhan dasar untuk air minum, air bersih untuk sanitasi, dan untuk pembangunan ekonomi seperti industri, rekreasi, pertanian dan pembangkit listrik. Sebagian kegiatan itu membutuhkan air permukaan, yaitu air sungai, sementara 
kualitas dan kuantitas sumber daya air sungai menurun akibat adanya pencemaran air dan pencemaran daerah tangkapan air. Permasalahan limbah cair yang berasal dari industri maupun limbah domestik, jika tidak dikelola dengan baik ketika masuk ke badan air sungai, akan menyebabkan kerusakan lingkungan sehingga akan merusak struktur dan fungsi dasar dari ekosistem sungai yang merupakan penunjang kehidupan manusia. Akibatnya, akan tercipta beban sosial, dan manusia itu sendiri yang akan menanggung beban pemulihannya. Oleh karena itu, menjaga fungsi lingkungan harus dilakukan karena merupakan investasi berharga bagi generasi mendatang untuk kelangsungan hidupnya (Aulia, 2014).

Berdasarkan permasalahan tersebut, untuk menciptakan keserasian antara hubungan manusia dengan lingkungan hidup di Kota Pekalongan yang merupakan kota yang terletak di bagian hilir atau bagian bawah yang merupakan daerah polutan trap, maka harus diiringi dengan peraturan perundang-undang atau landasan hukum. Maka, rumusan masalah dalam penelitian ini adalah "Bagaimana implementasi Peraturan Daerah No 9 Tahun 2015 tentang pengelolaan air limbah ditinjau atau dikaji berdasarkan konsep pembangunan berkelanjutan?"
Metode yang digunakan dalam penelitian ini adalah metode kualitatif dengan studi pustaka. Penelitian kualitatif adalah penelitian untuk memahami fenomena tentang apa yang dialami oleh subjek penelitian secara holistik dan dengan cara deskriptif dalam bentuk kata-kata dan bahasa pada suatu konteks khusus yang alamiah, serta dengan memandaatkan berbagai metode alamiah (Moloeng, 2007).

\section{Pendekatan Konsep Kebijakan Lingkungan}

Peraturan Daerah Nomor 9 Tahun 2015 Tentang Pengolaan Air Limbah di Kota Pekalongan

Indonesia merupakan negara kesatauan dan negara hukum yang menggambarkan bahwa hubungan antarlevel pemerintahan (pusat dan daerah) berlangsung secara inklusif (inclusif authority model), di mana otoritas pemerintah daerah tetap dibatasi oleh pemerintah pusat melalui suatu sistem kontrol yang berkaitan dengan pemeliharaan kesatuan. Indonesia merupakan negara yang luas. Oleh karena itu, diperlukan sub-national goverment sebagai unit pemerintah di tingkat lokal (daerah), dan otonomi daerah yang memberikan seluas-luasnya kepada daerah untuk mengatur dan mengurus rumah tangga masing-masing (Handayani, 2013).

Peraturan daerah mempunyai fungsi yaitu pembantuan yang tertuang pada Undang- 
Undang Nomor 23 Tahun 2014 tentang Pemerintah Daerah. Bab I ketentuan umum pasal 1 ayat 11 menyatakan bahwa "Tugas Pembantuan adalah penugasan dari Pemerintah Pusat kepada daerah otonom untuk melaksanakan sebagian Urusan Pemerintahan yang menjadi kewenangan Pemerintah Pusat atau dari Pemerintah Daerah provinsi kepada Daerah kabupaten/ kota untuk melaksanakan sebagian Urusan Pemerintahan yang menjadi kewenangan Daerah provinsi". Selain memiliki tugas pembantuan, perda kemudian menciptakan suatu fungsi. Pertama, sebagai instrumen kebijakan untuk melaksanakan otonomi daerah dan tugas pembantuan sebagaimana diamanatkan dalam Undang-Undang Dasar Negara Republik Indonesia Tahun 1945 dan Undang-Undang tentang Pemerintahan Daerah. Kedua, merupakan peraturan pelaksanaan dari Peraturan Perundangundangan yang lebih tinggi. Dalam fungsi ini, Peraturan Daerah tunduk pada ketentuan hierarki Peraturan Perundang-undangan. Dengan demikian Peraturan Daerah tidak boleh bertentangan dengan Peraturan Perundang-undangan yang lebih tinggi. Ketiga, sebagai penampung kekhususan dan keragaman daerah serta penyalur aspirasi masyarakat di daerah, namun dalam pengaturannya tetap dalam koridor Negara Kesatuan Republik Indonesia yang berlandaskan Pancasila dan Undang-Undang Dasar Negara Republik Indonesia Tahun 1945. Keempat, sebagai alat pembangunan dalam meningkatkan kesejahteraan daerah (Kemenkumham, 2011).

Dalam pembuatan Peraturan Daerah Pengelolaan Air Limbah belum ada peraturan perundang-undangan yang secara hirarki memerintahkan secara tegas untuk pembentukan Perda Pengelolaan Air Limbah dan materi muatan apa saja yang diatur dalam perda. Beberapa Peraturan Perundangundangan yang menjadi dasar landsan Peraturan Daerah Pengelolaan Air Limbah yaitu: (1) UUD Negara RI Tahun 1945; (2) UU No. 11 Tahun 1974 tentang pengairan; (3) UU No. 32 Tahun 2009 tentang Perlindungan dan Pengelolaan Lingkungan Hidup; (4) UU No. 25 Tahun 2009 tentang pelayanan Publik; dan (5) Peraturan Pemerintah Nomor 82 Tahun 2001 tentang Pengelolaan Kualitas Air dan Pengendalian Pencemaran Air (Direktorat PPLP Dinas Cipta Karya, 2015).

Pemerintah Kota Pekalongan kemudian membuat kebijakan berupa Perda Nomor 9 Tahun 2015 Tentang Pengelolaan Air Limbah di Kota Pekalongan yang mencakup tentang tata kelola air limbah di kota Pekalongan. Perda tersebut menjelaskan bahwa setiap tempat industri, rumah sakit, puskesmas, hotel, laboratorium, rumah potong hewan, 
peternakan, dan semua usaha dan atau kegiatan yang mengeluarkan limbah sebagai sisa hasil usaha atau kegiatan yang berwujud cair wajib melakukan pengembangan sistem pengelolaan air limbah berupa individu maupun terpusat (komunal). Tujuan dari dibuatkannya Perda Nomor 9 Tahun 2015 ini adalah untuk mengendalikan kualitas air limbah yang dibuang ke lingkungan atau ke perairan umum, sehingga kadar mutu air di Kota Pekalongan terjamin.

Perda No 9 Tahun 2015 Tentang Pengelolaan Air Limbah di Kota Pekalongan juga menjelaskan mengenai tata kelola air limbah, yakni dengan menggunakan IPAL. Hal tersebut tercantum pada Pasal 4 ayat 1, yaitu Setiap penanggungjawab usaha dan/atau kegiatan yang menghasilkan dan membuang air limbah wajib memiliki IPAL, guna mengolah air limbahnya agar sesuai dengan baku mutu air limbah. Kadar baku mutu air limbah wajib diji kualitasnya setiap 1 bulan 1 kali di laboratorium yang telah terakreditasi.

\section{Konsep Pembangunan Berkelanjutan}

Konsep pembangunan berkelanjutan telah menjadi konsep yang terkenal di dunia internasional sejak dipertegasnya konsep ini pada KTT Bumi di Rio de Jenairo pada tahun 1992. Kemudian, hampir seluruh negara menggunakan konsep pembangunan berkelanjutan sebagai jargon dari pembangunannya. Konferensi ini, yang juga disebut sebagai Earth Summit, merupakan softlaw agreement yang memuat 27 prinsip. Sepuluh diantaranya menjadi unsur penting pembangunan berkelanjutan, yaitu prinsip kedaulatan dan tanggung jawab negara (prinsip 2), prinsip keadilan antargenerasi (prinsip 3), prinsip keadilan intragenerasi (prinsip 5 dan 6), prinsip keterpaduan antara perlindungan lingkungan hidup dan pembangunan (prinsip 4), prinsip tanggung jawab bersama tetapi berbeda (prinsip 7), rinsip tindakan pencegahan (prinsip 11), prinsip bekerja sama dan bertetangga baik dan kerja sama internasional (prinsip 18, 19, dan 27), prinsip berkehati-hatian (prinsip 15), prinsip pencemaran membayar (prinsip 16), rinsip demokrasi dan peran serta masyarakat (prinsip 10) (Rahmadi, 2016).

Konsep pembangunan berkelanjutan pun kembali menjadi pembahasan dengan munculnya Sustainable Development Goals (SDGs) sebagai pengganti dari Millenium Development Goals (MDGs) (Fauzi, 2004). Pembangunan berkelanjutan dapat diartikan sebagai konsep pembangunan yang memenuhi kebutuhan masa kini tanpa mengorbankan hak pemenuhan kebutuhan-kebutuhan pada generasi yang akan datang. Dalam pembangunan berkelanjutan terkandung dua gagasan penting, yaitu (a) gagasan 'kebutuhan' 
yang merupakan kebutuhan manusia, dan (b) gagasan keterbatasan yang bersumber pada kondisi teknologi dan organisasi sosial terhadap kemampuan lingkungan untuk memenuhi kebutuhan kini dan hari depan. Pembangunan berkelanjutan juga sering dijabarkan dengan perbaikan kualitas hidup yang disesuaikan dengan daya dukung lingkungan (carrying capacity). Secara umum, keberlanjutan diartikan sebagai continuing without lessening yang berarti melanjutkan aktivitas tanpa mengurangi. Moldan dan Dahl (2007) memberikan pemahaman bahwa pembangunan berkelanjutan dapat dimaknai sebagai pembangunan yang mampu mempertahankan terjadinya pembangunan itu sendiri menjadi tidak terbatas. Marlina (2009) mengatakan pembangunan berkelanjutan tidak saja berkonsentrasi pada isu-isu lingkungan. Lebih luas dari itu, pembangunan berkelanjutan mencakup tiga lingkup kebijakan, yaitu pembangunan ekonomi, pembangunan sosial, dan perlindungan lingkungan, atau dapat disebut dengan Tiga Pilar Pembangunan Berkelanjutan.

Pada prinsipnya, terdapat tiga dimensi utama dari pembangunan berkelanjutan, yaitu lingkungan hidup, sosial dan ekonomi. Keberlanjutan lingkungan adalah di mana alam menyediakan udara bersih yang dapat kita hirup. Alam menyediakan segala hal untuk manusia, namun apakah manusia dapat tetap membangun fungsi-fungsi alam tersebut secara terus-menerus sehingga dapat secara berkelanjutan. Sedangkan maksud dari keberlanjutan ekonomi adalah upaya untuk meningkatkan kesejahteraan generasi sekarang tanpa mengurangi kemampuan alam, masyarakat dan ekonomi untuk menaikan kesejahteraan generasi masa depan. Dengan demikian, terdapat alur ekonomi yang berjalan terus-menerus, tanpa mengurangi tingkat kesejahteraan dari generasi ke generasi. Selanjutnya adalah keberlanjutan sosial, yaitu pembangunan yang berdimensi pada manusia dalam hal interaksi dan interdependesi yang erat kaitannya dengan aspek budaya. Pembangunan berkelanjutan bertujuan untuk menjaga keberlangusngan budaya dari sebuah masyarakat agar masyarakat tetap bisa eksis untuk menjalani kehidupan serta mempunyai sampai masa mendatang (Otto, 2004).

Haris (2000) menjelaskan bahwa konsep pembangunan berkelanjutan menjadi tiga aspek pemahaman, yaitu: keberlanjutan ekonomi yang diartikan sebagai pembangunan yang mampu menghasilkan barang dan jasa secara kontiniu untuk memelihara keberlanjutan pemerintahan dan menghindari ketidakseimbangan sektoral yang dapat merusak produksi pertanian dan industri; (2) keberlanjutan lingkungan, yaitu sistem 
keberlanjutan yang mampu memelihara sumber daya yang stabil, menghindari eksploitasi sumber daya alam dan fungsi penyerapan lingkungan. Konsep ini juga menyangkut pemeliharaan keanekaragaman hayati, stabilitas ruang udara dan fungsi ekosistem lainnya; (3) keberlanjutan sosial yang diartikan sebagai sistem yang mampu mencapai kesetaraan, penyediaan layanan sosial termasuk kesehatan, pendidikan, gender dan akuntabilitas politik.

\section{Pembahasan}

\section{Penanganan Limbah Batik di Pekalongan}

Pembangunan berkelanjutan adalah salah satu upaya manusia untuk memperbaiki mutu kehidupan dengan tetap berusaha untuk tidak melampaui ekosistem yang mendukung kehidupannya. Kini, masalah pembangunan berkelanjutan telah dijadikan sebagai isu penting yang terus-menerus disosialisasikan di tengah masyarakat. Seperti yang telah dijelaskan sebelumnya, bahwa pembangunan berkelanjutan memiliki tiga pemahaman atau dimensi seperti yang diungkapkan oleh Otto (2004) dan Haris (2000), yaitu dimensi ekologi atau lingkungan, dimensi sosial dan dimensi ekonomi.

\section{Dimensi Sosial}

Batik merupakan tekstil yang berasal dari kerajinan tangan tradisional dan diwariskan kepada generasi di Jawa dan sekitarnya sejak awal abad ke-19. Batik merupakan bahan yang dihiasi oleh pola-pola berupa titik dan garis yang dihasilkan oleh penerapan lilin panas dengan menggunakan canting tulis sebagai pena. Motif-motif batik tersebut kemudian melambangkan status sosial, masyarakat lokal, alam, sejarah dan warisan budaya (UNESCO, 2009). Akan tetapi pada perkembangannya, terjadi pengembangan citra penggunaan batik yang sebelumnya memberi kesan formal menjadi kesan formal dan informal (Permata, 2012). Kini, batik telah memiliki tempat tersendiri bagi penduduk di Indonesia. Terlebih semenjak diakuinya batik oleh UNESCO (Educational, Scientific, and Cultural Organisation) pada tanggal 2 Oktober 2009. Hal tersebut membuat industri batik semakin bermunculan di masing-masing daerah di Indonesia, salah satunya adalah di Kota Pekalongan yang merupakan ikon Kota Batik di Indoensia, dan juga terdapat kecenderungan peningkatan permintaan batik di Indonesia (Fitinline, 2013). Kerajinan batik merupakan salah satu industri kreatif yang berpotensi meningkatkan ekonomi masyarakat. Di Kota Pekalongan terdapat berbagai macam pengerajin batik, dari skala kecil (home industry), menengah, hingga skala besar yang produknya dapat menembus pasar internasional. 
Meningkatnya nilai dari batik menunjukan adanya dimensi sosial pada konsep pembangunan berkelanjutan. Adanya interaksi sosial berupa peningkatan 'branding' batik yang membuat nilai batik semakin tinggi dan produksi batik semakin meningkat merupakan salah satu bentuk dari dimensi sosial yang ada dalam pembangunan berkelanjutan. Hal tersebut sesuai dengan Otto (2004) yang menjelaskan bahwa pembangunan berkelanjutan tidak terlepas pada tiga aspek, yaitu lingkungan hidup, ekonomi dan sosial. Meningkatnya nilai batik seiring dengan diakuinya batik sebagai warisan dunia oleh UNESCO merupakan salah satu bukti dari adanya pembangunan berkelanjutan dari aspek sosial. Otto (2004) menyatakan bahwa keberlanjutan sosial yaitu pembangunan yang berdimensi pada manusia dalam hal interaksi yang erat kaitannya dengan aspek budaya. Batik merupakan warisan budaya Indonesia yang ada hingga sekarang.

Pembangunan berkelanjutan kemudian bertujuan untuk menjaga keberlangsungan budaya dari sebuah masyarakat agar tetap bisa eksis dalam menjalani kehidupan dan mempunyai kehidupan hingga masa mendatang. Hal ini menunjukan bahwa semenjak diakuinya batik sebagai warisan budaya oleh UNESCO, eksistensi batik semakin meningkat, ditandai dengan semakin meningkatnya permintaan produksi batik, dan hal ini menjadi bukti bahwa batik dapat terus ada hingga sampai pada masa mendatang.

\section{Dimensi Ekonomi}

Kota Pekalongan merupakan salah satu kota di Jawa Tengah yang memiliki jumlah UMKM yang cukup banyak dan didominasi oleh industri garmen dan batik, yaitu sebesar 90,10\% dari keseluruhan jumalh industri yang ada di Kota Pekalongan. Berdasarkan data dari Disperindag Provinsi Jawa Tengah (2007), Kota Pekalongan memiliki jumlah industri batik skala kecil sebanyak 714 industri, lebih banyak dibandingkan dengan kota-kota penghasil batik lain di Jawa Tengah. Secara keseluruhan, sektor industri batik menyumbang kurang lebih 26,29\% terhadap Pendapatan Asli Daerah (PAD) Kota Pekalongan.

Berdasarkan laporan Kementerian Perdagangan RI tahun 2012, nilai produksi batik tahun 2011 meningkat menjadi 3,9 triliun rupiah dibanding tahun 2010 yang sebesar 2,9 triliun rupiah. Nilai permintaan batik, khususnya ekspor, menunjukkan nilai yang terus meningkat. Dalam kurun waktu 2008 hingga 2012, rata-rata pertumbuhan ekspor batik sebesar 33,83\%. Bila dilihat pada kurun waktu 3 tahun terakhir, nilai ekspor yang dihitung dari total semua produk kain batik dan turunan batik menujukkan bahwa pada 
tahun 2010 sebesar USD 22,3 juta, USD 69 juta pada tahun 2011, dan meningkat menjadi USD 278 juta pada tahun 2012 (Kemenperin, 2012).

Besarnya output sektor industri ini tentu saja berdampak pada peningkatan pertumbuhan ekonomi di Kota Pekalongan. Menurut data dari BPS Provinsi Jateng (2011), laju pertumbuhan ekonomi Kota Pekalongan dari tahun 2006-2010 mengalami peningkatan. Hanya saja, pada tahun 2008, laju pertumbuhan ekonomi Kota Pekalongan mengalami penurunan sebesar $0,03 \%$ dari tahun sebelumnya. Hal ini disebabkan tingginya pesaing industri batik di Indonesia. Ditambah lagi dengan masuknya produk batik dari Cina. Namun kemudian, pertumbuhan ekonomi Kota Pekalongan kembali meningkat pada tahun 2009 sebesar $1,05 \%$ dan pada tahun 2010 kembali meningkat sebesar 0,28\%.

Peningkatan nilai ekonomi yang terusmenerus akibat industri batik ini menunjukan bahwa industri batik merupakan salah satu bentuk pembangunan berkelanjutan. Otto (2004) menjelaskan bahwa pembangunan berkelanjutan dalam dimensi ekonomi adalah upaya untuk meningkatkan kesejahteraan generasi sekarang tanpa mengurangi kemampuan alam, masyarakat, dan ekonomi untuk menaikkan kesejahteraan generasi masa depan, yang kemudian terdapat alur ekonomi yang berjalan terus-menerus tanpa mengurangi tingkat kesejahteraan dari generasi ke generasi. Pewarisan budaya batik dan tingginya permintaan batik membuat nilai ekonomi semakin bertambah dan menjamin kesejahteraan generasi yang akan datang sehingga akan muncul nilai ekonomi yang berjalan terus-menerus tanpa mengurangi kesejahteraan dari genearsi ke generasi. Sedangkan Harris (2000) menjelaskan bahwa keberlanjutan ekonomi adalah suatu pembangunan yang mampu menghasilkan barang dan jasa secara kontinu dan mampu memelihara keberlanjutan pemerintahan serta menghindari ketidakseimbangan sektoral yang dapat merusak produksi pertanian dan industri. Produksi batik yang terus-menerus dan berkelanjtan untuk menyeimbangkan sektoral dapat pula menjamin kesejahteraannya.

\section{Dimensi Lingkungan}

Berkah dari industri batik Pekalongan ternyata harus berbanding terbalik dengan dampak yang ditimbulkanya. Semakin pesatnya industri batik menunjukkan bahwa semakin banyak pula limbah yang dikeluarkan dan mengakibatkan permasalahan yang kompleks bagi lingkungan sekitar. Apalagi jika limbah yang dihasilkan dari industri batik tersebut dibuang langsung ke sungai.

Menanggapi hal tersebut, pemerintah Kota Pekalongan kemudian mengeluarkan 
Peraturan Daerah No 9 Tahun 2015 Tentang Pengelolaan Air Limbah. Perda ini dibuat dalam rangka penyeimbang atau solusi dari dampak yang ditimbulkan dari pembangunan berkelanjutan industri batik. Perda tersebut menjelaskan bahwa setiap penanggung jawab usaha dan/ atau kegiatan yang menghasilkan dan membuang air limbah wajib untuk memiliki IPAL, guna mengolah air limbahnya agas sesuai dengan baku mutu air limbah.

Menurunnya kondisi lingkungan berupa terjadinya cemaran air limbah merupakan salah satu ancaman dari pelaksanaan pembangunan berkelanjutan. Pemerintah Kota Pekalongan kemudian mengeluarkan solusi berupa Perda No 9 Tahun 2015 tentang Pengolahan Air Limbah, yang berfungsi sebagai penyeimbang agar pembangunan berkelanjutan dapat terus dilaksanakan. Hardjosoemantri (2000) menjelaskan bahwa hukum memiliki peranan yang penting dalam terlaksananya pembangunan berkelanjutan. Menurut Koesnadi Hardjosoemantri, pertama kali dalam evolusi konsep pembangunan berkelanjutan adalah upaya yang telah dilakukan guna menggariskan kerangka hukum yang komprehensif untuk menetapkan pembangunan berkelanjutan. Dalam mengemukakan pentingnya mekanisme hukum dalam tingkat nasional, regional, dan internaisonal untuk menetapkan dan melaksanakan pembangunan berkelanjutan, Harjosoemantri menyatakan bahwa hukum lingkungan dalam pengertiannya yang luas adalah sarana esensial dalam pencapaian pembangunan berkelanjutan (Hardjosoemantri, 2000). Oleh karena ini, adanya hukum berupa perda tersebut tentunya dapat menyelaraskan pembangunan berkelanjutan dari industri batik yang telah ada.

Diterbitkannya Perda Kota Pekalongan No 9 Tahun 2015 tersebut juga memenuhi beberapa unsur penting (prinsip) dalam pembangunan berkelanjutan, seperti prinsip keadilan antargenerasi, prinsip keterpaduan antara perlindungan lingkungan hidup dan pembangunan, dan prinsip tindakan pencegahan.

Pertama, prinsip keadilan antargenerasi (Intergenerational equity) dirumuskan dalam prinsip ke-3 Deklarasi Rio yang berbunyi "the right to development must be fulfilled so as to equitably meet development and environmental needs of present and future generations." Inti dari prinsip ini adalah generasi sekarang memiliki kewajiban menggunakan sumber daya dengan lebih hemat dan bijaksana serta melaksanakan konversi sumber daya alam sehingga sumber daya alam tetap tersedia dalam kualitas maupun kuantitas yang cukup untuk dimanfaatkan oleh generasi masa datang. Sangat bijaksana jika generasi 
sekarang tidak meninggalkan sumber-sumber air, tanah, udara yang telah tercemar untuk generasi mendatang, sehingga dapat digunakan untuk memenuhi kebutuhan mereka. Prinsip ini kemudian menjadi dasar pengembangan hukum lingkungan nasional maupun hukum internasional (Rahmadi, 2016). Prinsip keadilan antargenerasi (intergenerational equity) ini tercermin pada Peraturan Daerah Kota Pekalongan Nomor 9 Tahun 2015 Tentang Pengelolaan Air Limbah Pasal 2 ayat 2, seperti:

(2) Pengelolaan air limbah bertujuan untuk:

a. Mengendalikan kualitas air limbah yang dibuang ke lingkungan atau ke perairan umum;

b. Menjaga, melindungi, dan mempertahankan kualitas air permukaan dan air tanah sehingga dapat berfungsi sesuai dengan peruntukannya;

c. Meningkatkan upaya pelestarian fungsi lingkungan hidup dalam rangka mewujudkan pembangunan yang berkelanjutan dan berwawasan lingkungan.

Pasal tersebut menjelaskan mengenai tujuan dari pengelolaan limbah. Peraturan Daerah Nomor 9 Tahun 2015 Tentang Pengelolaan Air Limbah tersebut menyatakan secara jelas bahwa perda tersebut dibuat guna ikut serta dalam pelestarian alam yang telah digunakan untuk industri sebelumnya. Air limbah yang dibuang ke lingkungan diharapkan dapat dikelola terlebih dahulu sehingga dampaknya dapat lebih diminimalisir. Selain itu, upaya pelestarian lingkungan tersebut sebagai upaya mewujudkan pembangunan yang berkelanjutan dan berwawasan lingkungan.

Kedua, prinsip keterpaduan antara perlindungan lingkungan hidup dan pembangunan tercermin dalam Prinsip ke-4 Deklarasi Rio yang berbunyi "in order to achieve sustainable development, environment protection shall constitute an integral part of the development procces and cannot be considered in isolation form it". Inti dari prinsip ini adalah diberlakukannya AMDAL dan perlunya ketersediaan informasi lingkungan dalam proses pengambilan keputusan pemerintah (Rahmadi, 2016).

Prinsip ini tercermin dalam Perda Kota Pekalongan No 5 tahun 2015 Tentang Pengelolaan Air Limbah pada pasal 8, di mana selain setiap industri atau penanggungjawab usaha wajib memiliki IPAL sebagai sarana pengolahan air limbah, penangung jawab usaha dan atau kegiatan yang membuang air limbah ke air dan atau perairan umum wajib memiliki izin pembuangan air limbah. Izin tersebut salah satunya harus memenuhi persyaratan administrasi dan teknis seperti adanya dokumen AMDAL atau UKP-UPL atau dokumen lainnya yang dipersamakan 
dengan dokumen tersebut (Pasal 8 ayat 1: "Setiap penanggung jawab usaha dan/atau kegiatan yang membuang air limbah ke air dan/atau perairan umum wajib memiliki izin pembuangan air limbah." Pasal 8 ayat 3: "Persyaratan administrasi sebagaimana dimaksud pada ayat (2) meliputi: a. Isian formulir perohonan izin; b. Izin yang berkaitan dengan usaha dan/atau kegiatan; dan c. dokumen Amdal atau UKL-UPL, atau dokumen lain yang dipersamakan dengan dokumen dikamsud.")

Hal ini menunjukan bahwa setiap industri wajib memiliki AMDAL atau dokumen lingkungan pendukung lainnya. Tujuan adanya amdal tersebut adalah untuk menjaga dan meningkatkan kualitas lingkungan hidup serta menekan pencemaran sehingga dampak negatifnya dapat menjadi serendah mungkin.

Ketiga, prinsip tindakam pencegahan. Prinsip pencegahan mewajibkan agar langkah pencegahan dapat dilakukan sedini mungkin. Dalam konteks pengendalian pencemaran, perlindungan lingkungan paling baik dilakukan dengan cara pencegahan pencemaran daripada penanggulangan atau pemberian ganti rugi. Dalam Deklarasi Rio, pencegahan dirumuskan dalam Prinsip 11, yaitu "state all enact effective environmental legislation"... (Rahmadi, 2016). Salah satu prinsip tindakan pencegahan ini tercermin pada Perda Kota Pekalongan No 9 Tahun 2015 Tentang Pengelolaan Air Limbah Pasal 4 ayat 1 dan 2, seperti:

“(1) Setiap penanggung jawab usaha dan/atau kegiatan yang menghasilkan dan membuang air limbah wajib memiliki IPAL, guna mengolah air limbahnya agar sesuai dengan baku mutu Air Limbah

Setiap penanggungjawab usaha dan/ atau kegiatan yang telah memiliki IPAL dan belum berfungsi secara optimal wajib menyempurnakan IPAL nya hingga air limbah yang dibuang ke badan iar penerima sesuai baku mutu Air Limbah."

Penggunaan IPAL, baik skala komunal maupun rumah tangga, bertujuan agar masyarakat sadar dan mau berpartisipasi dalam pengelolaan air limbah guna terciptanya lingkungan yang bersih dan sehat. Pemerintah Pekalongan telah membangun Instalasi Pengolahan Air Limbah (IPAL) batik yang terletak di Kelurahan Jenggot pada tahun 2009, kemudian Pemerintah Pekalongan juga membangun IPAL batik yang terletak di Kelurahan Kauman (Dinas Penataan Kota dan Lingkungan Hidup Kota Pekalongan, 2007). Namun, penggunaan IPAL batik terpadu tersebut belum memadai dalam menangani pencemaran air. Mardiatno (2012) melaporkan bahwa IPAL batik di Kelurahan Jenggot hanya dapat mencakup sekitar 400 volume $\mathrm{m}^{3}$ per 
hari debit air limbah pembuangan. Sementara itu, total debit air limbah di Pekalongan meningkat tajam menjadi 700 volume $\mathrm{m}^{3}$ per hari. Selain itu, kedua IPAL tersebut tidak terletak di lokasi yang mencakup semua air limbah batik untuk seluruh produksi batik di Pekalongan.

Dampak dari belum maksimalnya penggunaan IPAL di Kota Pekalongan tentu saja mempengaruhi kadar baku mutu air dan pencemaran sungai di Kota Pekalongan. Berdasarkan penelitian yang dilakukan oleh Badan Lingkungan Hidup Kota Pekalongan pada tahun 2012, kondisi sungai di Pekalongan kadar BDO yang standarnya adalah $2 \mathrm{Mg} / \mathrm{l}$, di lapangan kadarnya mencapai $5 \mathrm{Mg} / \mathrm{l}$ (pada kelas 1 dan Pkl). Sementara itu, COD yang standarnya adalah $10 \mathrm{Mg} / \mathrm{l}$, di lapangan kadarnya mencapai $58,43 \mathrm{Mg} / \mathrm{l}$. Hasil dan inventarisasi tahun 2010-2015 menunjukan bahwa di Kota Pekalongan tingkat pencemaran cukup tinggi disebabkan oleh industri kecil maupun besar sebanyak 1.052 industri yang mencemari lingkungan dengan debit $4.440 \mathrm{M}^{3} /$ hari (Aulia, 2014).

Padahal, dalam Perda Kota Pekalongan No 9 Tahun 2015 Tentang Pengelolaan Air Limbah sudah dijelaskan mengenai kadar baku mutu limbah sebelum dibuang ke sungai, sehingga dapat meminimalisisr pencemaran sungai. Hal tersebut tercantum pada pasal 5 ayat 1, yang berbunyi:"Setiap penanggung jawab usaha dan/atau kegiatan yang membuang air limbah ke badan air penerima wajib memenuhi baku mutu air limbah yang telah ditetapkan."

Polemik mengenai industri batik dan limbahnya serta peraturan yang telah dibuat ini merupakan salah satu dampak dari pembangunan berkelanjutan. Peningkatan serta perkembangan usaha terutama yang memanfaatkan sumber daya alam, baik dalam bentuk industri maupun yang dilakukan oleh masyarakat, mempunyai potensi besar dalam memberikan kontribusi permasalahan lingkungan. Adanya pertumbuhan penduduk yang pesat membawa perubahan perilaku masyarakat, budaya, dan pola pembangunan yang menyebabkan terjadinya eksploitasi sumber daya alam secara besar-besaran dengan dalih untuk meningkatkan kesejahteraan masyarakat. Hal itu mengakibatkan semakin menipisnya ketersediaan sumber daya alam dan lingkungan hidup, khususnya sumber daya alam yang tidak dapat diperbaharui, dan kemudian menyebabkan pencemaran dan kerusakan lingkungan hidup (Aulia, 2014).

\section{Kesimpulan}

Pembangunan berkelanjutan juga sering dijabarkan dengan perbaikan kualitas hidup yang disesuaikan dengan daya dukung lingkungan (carrying capacity). Secara umum, 
keberlanjutan diartikan sebagai continuing without lessening, yang berarti melanjutkan aktivitas tanpa mengurangi. Terdapat tiga aspek pemahaman dalam pembangunan berkelanjutan, yaitu aspek sosial, ekonomi dan lingkungan. Secara umum, implementasi Perda Kota Pekalongan No 9 Tahun 2015 Tentang Pengelolaan Air Limbah merupakan suatu penyeimbang dari pembangunan berkelanjutan dari industri batik yang telah terlaksana. Namun, dalam pelaksanaannya, masih banyak hal yang belum terimplementasi secara maksimal, seperti penggunaan IPAL yang belum maksimal, kadar baku mutu air yang di atas standar, serta pencemaran air sungai. Hal tersebut merupakan dampak dari adanya pembangunan berkelanjutan, di mana adanya penggunaan sumber daya alam secara maksimal namun belum dibatasi oleh pengelolaan sumber daya alam itu sendiri agar tetap lestari, sehingga timbul pencemaran lingkungan.

Hasil dan pembahasan dalam penelitian menunjukkan bahwa industri batik memenuhi kriteria dalam konsep pembangunan berkelanjutan, yaitu dimensi ekonomi, sosial, dan lingkungan. Dalam hal dimensi lingkungan, adanya Peraturan Daerah Nomor 9 Tahun 2015 Tentang Pengelolaan Air Limbah menunjukan bahwa perda tersebut sebagai penyeimbang dari adanya pembangunan berkelanjutan. Beberapa prinsip pembangunan berkelanjutan yang terdapat dalam Perda No 9 Tahun 2015 Tentang Pengelolaan Air Limbah adalah sebagai berikut:

Pertama, prinsip keadilan antar generasi (Intergenerational equity). Prinsip ini terfokus pada pasal 2 ayat 2 yang menyatakan mengenai upaya dalam menjaga pelestarian lingkungan dengan cara melakukan pengelolaan air limbah, sehingga dampak pencemaran dapat diminimalisir dan dapat mewujudkan pembangunan berkelanjutan yang berwawasan lingkungan. Kedua, prinsip keterpaduan antara perlindungan lingkungan hidup dan pembangunan. Inti dari prinsip ini adalah diberlakukannya AMDAL dan perlunya ketersediaan informasi lingkungan dalam proses pengambilan keputusan pemerintah. Prinsip tindakam pencegahan. Pasal 8 ayat 3 menjelaskan bahwa setiap penangung jawab industri yang akan membuang limbah wajib memiliki izin pembuangan limbah, salah satu persyaratannya adalah adanya dokumen lingkungan seperti Amdal dan UKL-UPL. Ketiga, prinsip tindakan pencegahan. Inti dari prinsip ini adalah adanya tindakan pencegahan guna meminimalisir terjadinya dampak lingkungan. Pencegahan yang dilakukan dalam Perda No 9 Tahun 2015 adalah berupa diwajibkannya setiap penanggung jawab industri untuk memiliki IPAL, baik domestik 
maupun komunal. Dalam pelaksanaan di Kota Pekalongan, penggunaan IPAL komunal masih belum mampu untuk mengcover jumlah debit air limbah yang ada di Kota Pekalongan, sehingga timbul pencemaran air sungai. Hal tersebut ditandai dengan kadar BOD dan COD yang berada di atas nilai ambang batas.

\section{Daftar Pustaka}

Aulia, 2014. Urensi Penyusunan Peraturan Daerah Tentang Limbah di Wilayah Kota Pekalongan. Jurnal Justisia Vol. 2 No. 17 Desember 2014.

BPS Jateng, 2011. Jawa Tengah dalam Angka.

Dinas Penataan Kota dan Lingkungan Hidup Kota Pekalongan, 2007. Data Sentra Industri Kecil yang Air Limbahnya Berpotensi mencemari Lingkungan. KLH: Pekalongan.

Direktorat PPLP Ditjen Cipta Karya. 2015. Panduan Penyusunan Rancangan Peraturan Daerah Pengelolaan Air Limbah. Jakarta. Kementerian Pekerjaan Umum dan Perumahan Rakyat. http:/ciptakarya.pu.go.id/plp/upload/peraturan/

Buku_Panduan_Ranperda_Pengelolaan_Air_Limbah_LS.pdf.

Fauzi.A. 2004, Ekonomi Sumber Daya Alam dan Lingkungan, Teori dan Aplikasi, Gramedia Pustaka Utama, Jakarta.

Fitinline, 2013. Penetapan 2 Oktober sebagai Hari Batik Nasional. https://fitinline.com/article/ read/penetapan-2-oktober-sebagai-hari-batik-nasional/. Diakses tanggal 25 Oktober 2017.

Handayani, I Gusti. 2013. Pembentukan Peraturan Daerah Berbasis Lingkungan dalam Rangka Mewujudkan Praktik-Praktik Good Governance di Daerah. Jurnal Yustisia Edisi 85. http:// download.portalgaruda.org/article.php?article $=148707 \&$ val $=5869 \&$ title $=$ pembentukan $\%$ 20peraturan $\% 20$ daerah $\% 20 \% 20$ berbasis $\% 20$ lingkungan $\% 20$ dalam $\% 20$ rangka $\%$ 20mewujudkan\%20praktik-praktik\%20good\%20governance\%20di\%20daerah.

Hardjosoemantri, 2000. Hukum Tata Lingkungan. Gadjah Mada Press. Yogyakarta.

Haris, 2000. Human Resource management. second edition. USA : Harcourt Brace \& Company.

Heryando Palar. 2004. Pencemaran dan Toksikologi Logam Berat Jakarta: Rineka Cipta.

Isnawati, 2014. Limbah Batik Tidak Diolah, Air Bersih Terancam Punah, http:// www.suaramerdeka.com/v1/index.php/read/layar/2014/06/29/1161/Limbah-BatikTidakDiolah-Air-Bersih-Terancam-Punah. Diakses pada 2 Desember 2017 pukul 18.00.

Kemenkumham, 2011. Panduan Praktis Memahami Perancangan Peraturan Daerah. Jakarta. Direktorat Jenderal Peraturan Perundang-undangan. http://ditjenpp.kemenkumham.go.id/ files/jurnal/panduan-penulisan-perda.pdf hal 8. Diakses pada 2 Desember 2017 pukul 17.00.

Kemenperin, 2012. 2012: Indonesia Impor batik Senilai 285 Milyar. http:// www.kemenperin.go.id/artikel/5715/2012. Diakses 4 Desember 2017. 
Mardianto, A. 2012. Optimalizing Recruitment Strategy : Recruitment Analysis. Cetakan ke-1, Penerbit Pinasthika, Jakarta.

Marlina, Ani, 2009, karakteristik untuk mendefinisikan sustainable, wordpress: Jakarta.

Moldan, Reldrich dan Arthur Lyon Dahl. 2007. Challet ges to Sustainability Indicators.

Moleong, Lexy J. 2007.Metodologi Penelitian Kualitatif, Penerbit PT Remaja Rosdakarya. Offset, Bandung

Otto Soemarwoto, 2004, Ekologi, Lingkungan Hidup dan Pembangunan, Jakarta, Penerbit Djambatan.

Pemerintah Kota Pekalongan. 2016. https://pekalongankota.go.id/selayang-pandang/geografi. Diakses pada 4 Desember 2017 pukul 17.00.

Permata, 2012. Modes and Purposes of Consuming Batik Products: A Case Study of Airlangga University Students Allusion: 1:9-20.

Rahmadi, 2016. Hukum Lingkungan di Indonesia Edisi ke 2. Depok. Raja Grafindo Persada.

Rusda, Iys. 2015. Pengawasan Pemerintah Daerah Terhadap Pencemaran Limbah Industri Batik di Kota Pekalongan Pada Tahun 2010-2014. https://media.neliti.com/media/ publications/105625-ID-pengawasan-pemerintah-daerah-terhadap-pe.pdf. Diakses pada 4 Desember 2017 pukul 17.00.

UNESCO, 2009. Register of Best Safeguarding Practices. [Internet]. 